\title{
Effect of the traditional koumiss yeast produced in Turkey on some properties and carbonyl components of koumiss
}

\author{
Mehmet Çelebi ${ }^{1}$, Bedia Şimşek ${ }^{2}$, \\ Melike Özkan², Onur Acar², Elvan Özer² \\ 1 - Aydın Adnan Menderes University, Engineering Faculty, Department of \\ Food Engineering, Aydın, Turkey \\ 2 - Süleyman Demirel University, Engineering Faculty, Department of Food \\ Engineering, Isparta, Turkey
}

Keywords:

Koumiss

Yeast

Biogenic amine

Aroma

Carbonyl

Article history:

Received

29.08.2019

Received in

revised form

27.09.2019

Accepted

28.11.2019

\section{Corresponding author: \\ Mehmet Çelebi \\ E-mail: \\ mehmet.celebi@ adu.edu.tr}

\section{DOI:}

10.24263/23101008-2019-7-2-7

\section{Abstract}

Introduction. Koumiss produced from different types of milk (horse, cow and goat milk) by traditional koumiss yeast and observe the changes of aroma components and biogenic amines formations during the storage period (30 days) are presented in this work.

Materials and methods. Mare milk was used directly but the composition of cow and goat milk is different from that of mare milk, the compositions of these milk were used in the production of koumiss by emulating mare milk. Koumiss were produced with traditional yeast. Biogenic amine analysed with high performance liquid chromatography and aroma components was determined by headspace-gas chromatography.

Results and discussion. The lactic acidity value (\%) has gradually increased during the storage period of koumiss samples. The highest amount of ethyl alcohol was determined in koumiss $\left(30^{\text {th }}\right.$ day) produced from cow milk $(1.95 \%)$. Among the biogenic amines, the value of putrescine was found to be highest in koumiss produced from goat milk (5.68-5.86 ppm), while the cadaverine value was observed to reach to the highest values (2.66-9.74 ppm) in koumiss produced from horse milk. The amount of tyramine increased significantly in all koumiss samples. Phenyl ethylamine was determined only in goat milk koumiss $(0.64-0.84 \mathrm{ppm})$. The histamine value was observed to be at the highest ranges in the horse milk koumiss (4.80-6.52 ppm).

The aroma values on first day of storage in koumiss samples were determined as $0.78-3.76 \mathrm{ppm}$ acetaldehyde, $0.23-0.27 \mathrm{ppm}$ acetoin, 0.80- 1.62 ppm diacetyl, 0.03-0.06 ppm methanol, 7.2714.73 ppm butyl butyrate, $1.31-11.86 \mathrm{ppm}$ ethyl acetate. No statistically significant difference was found between the aroma substances in terms of milk type.

Conclusions. Biogenic amines in koumiss produced by traditional koumiss yeast with different types of milk in Turkey were below the acute toxicity doses. In terms of aroma substances, milk types was has the same effect on aroma substances statistically. 


\section{Introduction}

Koumiss is an old Turkish drink produced of mare milk having fragrant, sourish, light foamy, refreshing qualities and it is called as "Kumys", "Koumiss", "Kumiss" in the literature of different countries [1]. Traditional koumiss yeast in nomadic life at the end of the lactation period of the mares by adding goat milk into the leather bottles of koumiss and it is conserved until the next lactation period. When the mares begin to be milked, koumiss yeast is obtained by adding mare milk into the leather bottles in small amounts for five days [2].

When various properties of koumiss obtained from mare milk are examined; $\mathrm{pH} 7.03$, titratable acidity $(0.05 \%)$, density $1.033 \mathrm{~g} / \mathrm{cm} 3$, lactose $6.10-6.37 \%$, dry matter 10.20 $11.80 \%$, fat $1.21-1.90 \%$, protein $2.14-2.70 \%$, ash $0.42-0.50 \%$ alcohol amount $0.5-2.5 \%$ were observed $[2,3]$. It was determined that not only the lactose ratio decreases but also protein ratio decreases since proteins break the longer koumiss is stored. It is determined that also a significant decrease in specific gravity takes place too. However, it was determined that acidity and alcohol content had increased [4].

Cow milk and mare milk differ significantly in terms of composition. Mare milk is richer than cow and goat milk in terms of lactose content. Since cow, sheep, goat milks are not suitable to produce koumiss, using them by emulating mare milk has been reported to be appropriate $[5,6]$. Cow milk has been tried to make suitable for koumiss production by adding water, whey, glucose or saccharose, ascorbic acid in different ratios to increase sugar content, by reducing fat content of cow milk or using membrane technologies [6,7].

Aroma of koumiss is originated from compounds such as propyl alcohol, butyl alcohol, propionic acid, glycerine, aldehydes, acetone, various esters and volatile acids resulting from fermentation of lactic acid and alcohol [3]. Esters are formed from the reaction between organic acids and alcohols in koumiss. Traditional koumiss yeast due to containing lactic acid bacteria and yeasts, there may be differences at the taste and aroma formation in the product $[8,9]$.

The aim of this study is to determine the chemical properties, aroma substances and biogenic amine contents of the koumiss samples produced by using traditional koumiss yeast of horse, goat and cow's milk throughout its storage period. Determine the effect of milk types on the aroma substances of koumiss. In addition, observing the biogenic amine formations that cause carcinogenic toxic poisoning and the effects of milk species diversity in the traditional koumiss are among the objectives of this study.

\section{Materials and methods}

\section{Materials}

\section{Koumiss Production}

Preparation of mare, cow and goat milk. Mare milk was used directly for the production of koumiss without separating its fat. Since the composition of cow and goat milk is different from that of mare milk, the compositions of these milk were used in the production of koumiss by emulating mare milk. In order to simulate mare milk, fat of cow and goat milk was adjusted according to the composition of mare milk (0.5\%). Then $2.5 \%$ lactose (ENKA Dairy A.Ş. in Konya/Turkey) was added to these milk types. 
Preparation of koumiss yeast. The traditional koumiss yeast obtained from İzmir Alaş Koumiss Production Farm - İzmir/Turkey has been used as bulk culture. For the preparation of yeast, 2-3 minutes heat treatment at $90-92{ }^{\circ} \mathrm{C}$ was applied to the mixture added $90 \%$ water, $3.2 \%$ milk powder, $5.8 \%$ whey powder and $1 \%$ lactose. It was stirred by adding traditional koumiss bulk culture of $150-200 \mathrm{ml}$ cooling to room temperature with the $\mathrm{pH}$ value 5.6-5.7. Koumiss were incubated for 16 to 17 hours at $22{ }^{\circ} \mathrm{C}$. until $\mathrm{pH}$ value 4.4-4.5 and stored in the refrigerator. One day later it was used as koumiss yeast.

Production of koumiss. The same procedures were applied to all types of milks used at testing. Firstly, mare, cow, and goat milk were pasteurized for 30 minutes at $70{ }^{\circ} \mathrm{C}$. Then, $10 \%$ of koumiss starter culture at $28-30{ }^{\circ} \mathrm{C}$ was added to milks cooled at $30{ }^{\circ} \mathrm{C}$. At the $1^{\text {st }}$ hour following the start of fermentation, first stirring was carried out around 5-10 minutes. After then the stirring procedure was applied for 1-2 minutes at every other hour until the $\mathrm{pH}$ was 4.8 . The last 5 minutes of stirring was carried out when $\mathrm{pH}$ was 4.8. By filling in bottles at this $\mathrm{pH}$, the product was cooled to $4^{\circ} \mathrm{C}$ and stored at the same temperature. Koumiss were stored at the refrigerator temperature for 30 days and analysis were carried out on the $1^{\text {st }}, 15^{\text {th }}$ and $30^{\text {th }}$ days.

\section{Chemical analysis of raw milks and the koumiss}

Analysis of raw milk and koumiss were determined according to the total dry substance method described in [10]. Milk fat was determined using gerber method [11]. Specific gravity was determined with volumetric pycnometer (Glass Tube, $10 \mathrm{~mL}$, Istanbul, Turkey) [12]. Titration acidity in raw milk and koumiss were determined as lactic acid \% according to the method of AOAC [13]. While $\mathrm{pH}$ was measured with $\mathrm{pH}$ meter (WTW pH 3110, Germany). Alcohol content was prescribed with pycnometric method [14].

\section{Biogenic amine analysis}

Sample preparation. After $50 \mathrm{ml}$ of the samples were homogenized for 15 minutes with $50 \mathrm{ml}$ of $0.2 \mathrm{M}$ hydrochloric acid, the mixture was centrifuged at $2150 \mathrm{rpm}$ for 30 minutes. In the sample cooled to $4{ }^{\circ} \mathrm{C}$, the separated phase at the top was collected. The sample filtered from Whatman 42 filter paper was derivatized before being analysed with High Performance Liquid Chromatography (HPLC) [15].

Derivatization. $400 \mathrm{~mL}$ to the sample, $400 \mathrm{ml} \mathrm{N}_{2} \mathrm{CO}_{3}\left(2 \mathrm{~g} / 100 \mathrm{ml} \mathrm{H}_{2} \mathrm{O}\right)$ and $400 \mathrm{ml}$ densyl chloride $\left(10 \mathrm{mg} / 1 \mathrm{ml}\right.$ acetone) added $40{ }^{\circ} \mathrm{C}$ incubated in water bath for 30 minutes. $200 \mathrm{~m} 1 \mathrm{Na}-\mathrm{L}-\mathrm{glutamate}$ monohydrate $\left(200 \mathrm{mg} / 4 \mathrm{ml} \mathrm{H}_{2} \mathrm{O}\right)$ is added to the solution and incubated at the same temperature for another 1 hour. After incubation, $1 \mathrm{ml}$ of acetonitrile is added to the mixture and centrifuged at $2500 \mathrm{rpm}$ for $10 \mathrm{~min}$. Supernatant liquid is removed and injected to HPLC.

Characteristics of the chromatography device used. A diode array detector $(220 \mathrm{~nm})$, pump (LC - 10Advp), system controller (SCL - 10Avp), Degasser (DGU - 14A), Column oven (CTO $-1 \mathrm{CVp}$ ) and column (Prodigy 5m A Shimadzu HPLC device with ODS (2) (250 $\mathrm{x} 4.6 \mathrm{~mm}$ ) was used for biogenic amine analysis.

Chromatographic conditions. The column temperature of the HPLC device was set at $30{ }^{\circ} \mathrm{C}$ and the flow rate to $1.0 \mathrm{ml} / \mathrm{min}$. For the mobile phase, buffer ( $\mathrm{pH} 8$ ) was prepared using $0.1 \mathrm{M}$ tris, $0.1 \mathrm{M}$ acetic acid and water in $2: 1: 2$ ratios, respectively. To prepare solvent A; $30 \mathrm{ml}$ buffer, $550 \mathrm{ml}$ acetonitrile, $420 \mathrm{ml}$ distilled water were used. Solvent B was prepared by mixing $2 \mathrm{ml}$ of buffer, $900 \mathrm{ml}$ of acetonitrile and $100 \mathrm{ml}$ of distilled water. 


\section{Aroma components analysis}

Analysis of the aroma components was determined by gas chromatography (GC) [16]. The sample was put in the headspace vial and analysed.

Properties of the chromatography device used: GC/MS (Gas Chromatography, mass spectrometry), the oven was kept at $35{ }^{\circ} \mathrm{C}$ for 2 minutes, the temperature was increased to $240{ }^{\circ} \mathrm{C}$ with an increase of $5{ }^{\circ} \mathrm{C} / \mathrm{min}$ and kept at $24{ }^{\circ} \mathrm{C}$ for 20 minutes. $\mathrm{CP}$ WAX $(50 \mathrm{~m} \times 0.32$ id) was used as the column. The injection temperature was set to $180{ }^{\circ} \mathrm{C}$. The detector temperature is $200{ }^{\circ} \mathrm{C}$.

Headspace conditions: Headspace sampler parameters are as follows: head pressure 27 psi, 5 min. thermostat time, $90{ }^{\circ} \mathrm{C}$ needle temperature, $120{ }^{\circ} \mathrm{C}$ transfer line temperature, 0.5 min of pressurization time and 0.08 min of injection time [16].

\section{Microbiology analysis}

The count of total aerobic mesophilic bacteria count was conducted according to Plate Count agar (PCA) [17]. Incubation was performed at $35^{\circ} \mathrm{C}$ for 48 h., yeast-mold count according to Dicloran Rose Bengal Chloramphenicol agar (DRBC) (at $25^{\circ} \mathrm{C}$ for $3-5$ days) and total coliform bacteria (at $37{ }^{\circ} \mathrm{C}$ for 48 h.) counting according to Davis [18].

\section{Statistical analysis}

Variance analysis was performed to determine whether milk types had any effect on the samples examined or not. Duncan Multiple Comparison Test was applied to the results with the purpose of determining the effect of different effect from the main variation sources [19]. Statistical analysis was performed using SPSS 17.0 program [20].

\section{Results and discussion}

Chemical properties of raw milk used in koumiss production are shown in Table 1.

Characteristics of raw milk used in koumiss production

Table 1

\begin{tabular}{|l|c|c|c|}
\hline & Raw horse milk & Raw cow milk & Raw goat milk \\
\hline Dry-matter $(\%)$ & $10.58 \pm 1.24^{*}$ & $8.72 \pm 0.33$ & $9.40 \pm 0.28$ \\
\hline Specific gravity $\left(\mathrm{g} / \mathrm{cm}^{3}\right)$ & $1.031 \pm 0.00$ & $1.031 \pm 0.00$ & $1.038 \pm 0.00$ \\
\hline $\mathrm{pH}$ & $7.00 \pm 0.15$ & $6.79 \pm 0.14$ & $6.80 \pm 0.01$ \\
\hline Lactic acid (\%) & $0.05 \pm 0.00$ & $0.16 \pm 0.01$ & $0.17 \pm 0.02$ \\
\hline Fat $(\%)$ & $0.50 \pm 0.01$ & $3.20 \pm 0.01$ & $4.55 \pm 0.02$ \\
\hline
\end{tabular}

*Standart Deviation

While fat free dry substance content of horse milk was found as $10.58 \%$ this value was determined as $9.40 \%$ in goat milk. The specific gravity of cow and horse milk was determined $1.031 \mathrm{~g} / \mathrm{cm}^{3}$, while goat milk had $1.038 \mathrm{~g} / \mathrm{cm}^{3}$. The $\mathrm{pH}$ of the goat milk was found as 6.80 and $\mathrm{pH}$ of the horse milk was 7.00. It was observed that the lactic acid level of horse milk 
was $0.05 \%$ and cow milk was higher $(0.16 \%)$. Fat content of goat milk was determined as $4.55 \%$, while cow milk was $3.20 \%$ and horse milk was $0.50 \%$.

Küçükçetin [5] in his study determined horse, goat and cow milk specific gravity values respectively $1.034 \mathrm{~g} / \mathrm{cm}^{3}, 1.035 \mathrm{~g} / \mathrm{cm}^{3}$ and $1.038 \mathrm{~g} / \mathrm{cm}^{3}$ whereas $\mathrm{pH}$ values of horse, goat and cow milk as $6.98,6.18,6.71$. Lactic acid (\%) values were determined as $0.08 \%$ in horse milk, $0.18 \%$ in cow milk and $0.14 \%$ in goat milk. While dry substance values of horse milk were found between $10.1 \%$ and $11.4 \%$, it was determined that the dry substance value of modified cow milk as $9.15 \%$. In studies conducted fat values of cow and goat milk were determined respectively as $1.21 \%, 3.61 \%$ and $4.10 \%[21,22,23]$. The raw milk analysis findings of the researchers show similarity with this study.

\section{Chemical analysis results in koumiss}

Chemical properties of koumiss samples during 30 days storage are presented in Table 2.

Chemical results of koumiss which is produced from different types of milk
in different periods of storage

Table 2

\begin{tabular}{|l|c|c|c|c|}
\hline \multirow{3}{*}{ Chemical Analysis } & \multirow{2}{*}{ Samples } & \multicolumn{3}{|c|}{ Storage Periods } \\
\cline { 2 - 5 } & & 1 day & 15 day & 30 day \\
\hline \multirow{3}{*}{$\mathrm{pH}$} & $\mathrm{A}$ & $4.47 \pm 0.14$ & $3.43 \pm 0.35$ & $3.22 \pm 0.17$ \\
\cline { 2 - 5 } & $\dot{\mathrm{I}}$ & $4.63 \pm 0.04$ & $3.46 \pm 0.29$ & $3.30 \pm 0.21$ \\
\cline { 2 - 5 } & $\mathrm{K}$ & $4.55 \pm 0.23$ & $3.53 \pm 0.39$ & $3.37 \pm 0.16$ \\
\hline \multirow{3}{*}{$\begin{array}{l}\text { Lactic acid value } \\
(\%)\end{array}$} & $\mathrm{A}$ & $0.56 \pm 0.04$ & $1.20 \pm 0.54$ & $1.92 \pm 0.27$ \\
\hline \multirow{3}{*}{$\begin{array}{l}\text { Specific gravity } \\
\text { value } \\
\left(\mathrm{g} / \mathrm{cm}^{3}\right) *\end{array}$} & $\dot{\mathrm{I}}$ & $0.73 \pm 0.09$ & $1.33 \pm 0.31$ & $2.05 \pm 0.24$ \\
\hline \multirow{3}{*}{$\begin{array}{l}\text { Dry-matter } \\
(\%) *\end{array}$} & $\mathrm{~K}$ & $1.02 \pm 0.08$ & $1.53 \pm 0.45$ & $2.28 \pm 0.19$ \\
\cline { 2 - 5 } & $\mathrm{A}$ & $1.034 \pm 0.00^{\mathrm{bB}}$ & $1.031 \pm 0.00^{\mathrm{bB}}$ & $1.028 \pm 0.00^{\mathrm{bA}}$ \\
\hline \multirow{3}{*}{$\begin{array}{l}\text { Ethyl alcohol value } \\
(\%) *\end{array}$} & $\mathrm{I}$ & $1.037 \pm 0.00^{\mathrm{bB}}$ & $1.033 \pm 0.00^{\mathrm{bB}}$ & $1.030 \pm 0.00^{\mathrm{bA}}$ \\
\cline { 2 - 5 } & $\mathrm{A}$ & $9.04 \pm 0.57^{\mathrm{bB}}$ & $9.02 \pm 1.06^{\mathrm{bB}}$ & $8.31 \pm 1.33^{\mathrm{bA}}$ \\
\cline { 2 - 5 } & $\dot{\mathrm{I}}$ & $10.48 \pm 1.04^{\mathrm{bB}}$ & $9.40 \pm 1.93^{\mathrm{bB}}$ & $8.40 \pm 1.51^{\mathrm{bA}}$ \\
\cline { 2 - 5 } & $\mathrm{K}$ & $12.40 \pm 0.95^{\mathrm{aB}}$ & $11.45 \pm 0.20^{\mathrm{aB}}$ & $10.67 \pm 0.92^{\mathrm{aA}}$ \\
\cline { 2 - 5 } & $\mathrm{A}$ & $0.69 \pm 0.36^{\mathrm{aC}}$ & $1.22 \pm 0.06^{\mathrm{aB}}$ & $1.52 \pm 0.88^{\mathrm{aA}}$ \\
\cline { 2 - 5 } & $\dot{\mathrm{I}}$ & $0.85 \pm 0.50^{\mathrm{aC}}$ & $1.34 \pm 0.12^{\mathrm{aB}}$ & $2.11 \pm 0.39^{\mathrm{aA}}$ \\
\hline
\end{tabular}

*Difference between groups have determined that significant showed as small letter. Difference between times have demonstrated that significant showed as capital letter $(\mathrm{p}<0.01)$, A: Koumiss which is produced from horse milk, I: Koumiss which is produced from cow milk, K: Koumiss which is produced from goat milk 
It was determined that the $\mathrm{pH}$ value decreased in all koumiss samples during the storage period. The $\mathrm{pH}$ value of the milk produced by horse milk was determined as 4.47 on the $1^{\text {st }}$ day of storage. It was found that the $\mathrm{pH}$ value decreased at the end of storage. While the $\mathrm{pH}$ value was observed as 4.63 on the $1^{\text {st }}$ day of the cow milk used in koumiss, the $\mathrm{pH}$ value was decreased as 3.30 at the end of the storage. When the $\mathrm{pH}$ values of the koumiss were examined, it was observed that the effect of the type of milk and the change in storage time was not significant $(\mathrm{p}<0.01)$.

In Küçükçetin et al. [7] study, the $\mathrm{pH}$ of koumiss produced of modified cow and mare milk on day 1 of the storage was determined as 4.60 . Whereas on the 15 th day, the $\mathrm{pH}$ values were 4.41 and 4.33, respectively [7]. The $\mathrm{pH}$ values were found to be lower than the results of this study.

It was determined an increase at the lactic acid values of all koumiss samples during the storage period. The highest lactic acid value (2.28\%) is observed in koumiss produced of goat milk at the end of the storage. The $1^{\text {st }}$ day lactic acid value $(0.56 \%)$ of koumiss sample produced of horse milk was determined to be at the lowest level. Akuzawa and Suruno [24] reported that the lactic acid content of koumiss was between $0.6 \%$ and $1.0 \%$. The lactic acid values $\%$ of all samples were slightly higher than the results reported by the researchers.

The specific gravity of koumiss produced of horse milk was $1.034 \mathrm{~g} / \mathrm{cm}^{3}$ on 1 st day, it was observed that it dropped to $1.028 \mathrm{~g} / \mathrm{cm}^{3}$ value on $30^{\text {th }}$ day. This values are $1.037 \mathrm{~g} / \mathrm{cm}^{3}$ and $1.030 \mathrm{~g} / \mathrm{cm}^{3}$ at the koumiss produced of cow milk, respectively. The values found in koumiss that goat milk used in its production were found as $1.040 \mathrm{~g} / \mathrm{cm}^{3}, 1.038 \mathrm{~g} / \mathrm{cm}^{3}$ respectively. It was determined that milk type and storage duration have statistically significant effect on specific gravity values $(\mathrm{p}<0.01)$.

In a study on the properties of koumiss produced by using traditional koumiss yeast, it was determined that the specific gravity values of koumiss samples decreased during the storage period [25]. It is found that the koumiss study bear a resemblance from this aspect.

The dry substance ratio of the horse milk koumiss samples during storage was determined as (8.31-9.04\%). Dry substance values of koumiss show similar values with result of the study of Kinik et al. [26].

Although the type of ethyl alcohol contained in the samples did not significantly affect the type of raw milk, the difference between the times was found to be statistically significant $(\mathrm{p}<0.01)$. The lowest ethyl alcohol content $(0.64 \%)$ was determined in the goat milk koumiss sample while the highest value $(2.11 \%)$ was found in the cow milk koumiss sample.

Choi [27] found ethyl alcohol ratio in the product known as airag similar to koumiss produced of mare milk in Mongolia between 1.44-2.57\%. In koumiss studies produced of mare milk, the ethyl alcohol values were found to be between $0.7-2.6 \%[24,28,29]$.

\section{Biogenamine results of koumiss}

The amount of biogenic amines that koumiss samples contain during milk storage according to their milk types are shown in Table 3.

It is reported that as a result of interaction between microbial flora present in starter culture causes and normal microbial flora in milk causes directly or indirectly the formation of biogenic amines [30]. It has been shown that the types of milk used in production and the pasteurization temperature applied to milk also affect the formation of biogenic amines [31]. 
Table 3

Biogenic amine values (ppm) of koumiss which is produced from different types of milk in different periods of storage

\begin{tabular}{|c|c|c|c|c|}
\hline \multirow{2}{*}{ Biogenic Amine Values } & \multirow{2}{*}{ Samples } & \multicolumn{3}{|c|}{ Storage Periods } \\
\hline & & 1 day & 15 day & 30 day \\
\hline \multirow{3}{*}{ Putrescine } & A & $4.33 \pm 0.46$ & $2.60 \pm 0.55$ & $4.21 \pm 1.25$ \\
\hline & $\dot{\mathrm{I}}$ & $3.90 \pm 0.94$ & $4.75 \pm 0.93$ & $4.65 \pm 0.95$ \\
\hline & $\mathrm{K}$ & $1.09 \pm 0.37$ & $5.86 \pm 4.83$ & $5.68 \pm 4.92$ \\
\hline \multirow{3}{*}{ Cadaverine } & $\mathrm{A}$ & $9.74 \pm 1.16$ & $2.66 \pm 1.40$ & $4.00 \pm 1.07$ \\
\hline & $\dot{\mathrm{I}}$ & $3.47 \pm 0.29$ & $3.01 \pm 1.38$ & $1.70 \pm 0.53$ \\
\hline & $\mathrm{K}$ & $4.64 \pm 3.54$ & $5.76 \pm 3.56$ & $4.42 \pm 3.92$ \\
\hline \multirow{3}{*}{ Histamine $^{*}$} & A & $4.80 \pm 0.12^{\mathrm{aA} *}$ & $5.51 \pm 1.08^{\mathrm{aA}}$ & $6.52 \pm 0.06^{\mathrm{aB}}$ \\
\hline & $\dot{\mathrm{I}}$ & $4.55 \pm 0.29^{\mathrm{bA}}$ & $4.67 \pm 0.18^{\mathrm{bA}}$ & $4.90 \pm 0.18^{\mathrm{bB}}$ \\
\hline & $\mathrm{K}$ & $3.77 \pm 0.60^{\mathrm{bA}}$ & $4.70 \pm 0.17^{\mathrm{bA}}$ & $4.86 \pm 0.40^{\mathrm{bB}}$ \\
\hline \multirow{3}{*}{ Tyramine } & $\mathrm{A}$ & $1.88 \pm 0.07$ & $12.48 \pm 10.21$ & $29.15 \pm 4.35$ \\
\hline & $\dot{\mathrm{I}}$ & $1.84 \pm 0.16$ & $13.08 \pm 6.71$ & $23.85 \pm 0.45$ \\
\hline & $\mathrm{K}$ & $2.14 \pm 0.31$ & $23.71 \pm 17.39$ & $27.40 \pm 5.90$ \\
\hline \multirow{3}{*}{ Tryptamine } & $\mathrm{A}$ & ND & ND & ND \\
\hline & $\dot{\mathrm{I}}$ & ND & ND & ND \\
\hline & $\mathrm{K}$ & ND & $\mathrm{ND}$ & ND \\
\hline \multirow{3}{*}{ 2-Phenylethylamine } & $\mathrm{A}$ & ND & ND & ND \\
\hline & $\dot{\mathrm{I}}$ & ND & ND & ND \\
\hline & $\mathrm{K}$ & ND & $0.84 \pm 0.72$ & $0.64 \pm 0.20$ \\
\hline
\end{tabular}

*Difference between groups have determined that significant showed as small letter. Difference between times have demonstrated that significant showed as capital letter $(\mathrm{p}<0.01), \mathrm{A}$ : Koumiss which is produced from horse milk, İ: Koumiss which is produced from cow milk, K: Koumiss which is produced from goat milk; ND: Not detected.

Some polyamines (such as putrescine, spermidine, spermine and cadaverine) are indispensable components for living cells. Nucleic acid functions and protein synthesis is also important in the regulation of cell membrane since they play a role in the stabilization $[32,30]$. Although putrescine and cadaverine have no direct toxic effect, they have been indicated to increase the toxic effects of other amines. It has also been reported that putrescine and cadaverine can produce carcinogenic compounds by reacting with nitrite [30,33].

When samples of koumiss obtained from different milk samples were examined, it was observed that milk type and storage time were not significant in putrescine values $(\mathrm{p}<0.01)$. Although the putrescine values of the koumiss produced of horse and cow milk were close to each other on the last day of storage, the putrescine value of koumiss produced of goat milk sample was found to be approximately $1 \mathrm{ppm}$ higher. At a study conducted by Til et al. [34] on mice, acute toxicity dose for putrescine some orally taken biogenic amines causes was determined as $>2000 \mathrm{mg} / \mathrm{kg}$. When the putrescine values in the study were examined, it 
was observed to be lower than the acute toxicity dose Til et al. [34] determined in their own study.

The koumiss samples produced of goat and horse milk was found that the highest level cadaverine (4.42 ppm, $4.00 \mathrm{ppm}$, respectively). But the lowest level (1.70 ppm) was determined in the koumiss samples produced of cow milk. The toxicity dose caused by cadaverine was reported to be $>2000 \mathrm{mg} / \mathrm{kg}[34,30]$. From the reported toxicity dose, the cadaverine levels of all the samples in the study were found to be lower.

Histamine is a chemical that exhibits strong biological activity. It stimulates cardiovascular system, uterus, intestine and smooth muscles, respiratory tract, sensory motor neurons in the body and controls gastric acid secretion. Histamine poisoning may occur due to the consumption of foods containing high levels of histamine [35]. The toxic dose for histamine is reported to be $>1000 \mathrm{mg} / \mathrm{kg}$. The critical dose of oral histamine is estimated to be between 100 and $200 \mathrm{mg}$ [36]. In the study, histamine level at the end of storage in koumiss samples produced of horse milk determined as $6.52 \mathrm{ppm}$. This value is observed to be below the critical dose of oral histamine reported by of Aygun et al. [36].

Thyamin is an important biogenic amine whose antioxidative activity increases due to the amount it contains [37]. Like histamine and serotonin also tyramine is one of necessary amines in the operation of nerve system and control of blood pressure. Like histamine and phenylethylamine also tyramine is among the amines having the highest toxic effect. $100-$ $800 \mathrm{mg} / \mathrm{kg}$ values for tyramine have been reported as toxic doses in foods $[35,38,39,40]$. When the tyramine values were examined in this study, it was observed that the samples of koumiss produced of horse milk had the highest tyramine $(29.15 \mathrm{ppm})$ value at the end of the storage. Küçükçetin [5], determined increase in tyramine levels during storage period. He also determined that koumiss samples produced of mare milk contain more tyramine than the ones produced of cow milk. It has similar characteristics with the findings of the study.

It is known that tryptamine has an elevating effect on blood pressure [41]. No tryptamine was detected in none of the samples during storage.

During storage, 2-phenylethylamine content was not found in horse and cow milk koumiss samples, but determined in goat milk koumiss sample. It has been reported that 2phenylethylamine taken from foods in individuals sensitive to migraine attacks can trigger migraine attacks and increase blood pressure. The toxic dose for 2-phenylethylamine was determined as $30 \mathrm{ppm}[42,43]$. The maximum amount of phenylethylamine determined in the study was determined as $0.84 \mathrm{ppm}$. It has been observed that this level not causing any toxicity.

Özdestan and Üren [44] reported that they did not detect 2-phenylethylamine content on the $7^{\text {th }}$ day of storage of 10 different kefir samples. Phenylethylamine was not detected on $1^{\text {st }}$ day of the koumiss samples.

\section{Aroma Substances Result of Koumiss}

Some carbonyl components of the koumiss samples are shown in Table 4.

The highest acetaldehyde value $(3.97 \mathrm{ppm})$ during storage was determined on the $30^{\text {th }}$ day of the horse milk koumiss sample.

According to the research of Topuz [25], the effect of different fermentation durations on the development of acetaldehyde was reported to be statistically different from each other. Differences in the amounts of acetaldehyde in storage period of samples of koumiss were also observed. 
Aroma substances results of koumiss which is produced from different types of milk in different periods of storage

\begin{tabular}{|l|c|c|c|c|}
\hline \multirow{3}{*}{ *Aroma Substances } & \multirow{2}{*}{ Samples } & \multicolumn{3}{|c|}{ Storage Periods } \\
\cline { 2 - 5 } & & 1 day & 15 day & 30 day \\
\hline \multirow{3}{*}{ Acetaldehyde (ppm) } & $\mathrm{A}$ & $3.76 \pm 3.45$ & $2.66 \pm 2.29$ & $3.97 \pm 1.07$ \\
\cline { 2 - 5 } & $\dot{\mathrm{I}}$ & $1.62 \pm 1.41$ & $1.81 \pm 1.03$ & $1.19 \pm 0.20$ \\
\cline { 2 - 5 } & $\mathrm{K}$ & $0.78 \pm 0.68$ & $7.93 \pm 5.76$ & $1.06 \pm 0.10$ \\
\hline \multirow{3}{*}{ Acetoin (ppm) } & $\mathrm{A}$ & $0.27 \pm 0.06$ & $0.29 \pm 0.04$ & $0.10 \pm 0.18$ \\
\cline { 2 - 5 } & $\dot{\mathrm{I}}$ & $0.23 \pm 0.00$ & $0.22 \pm 0.002$ & $\mathrm{ND}$ \\
\cline { 2 - 5 } & $\mathrm{K}$ & $0.23 \pm 0.19$ & $0.28 \pm 0.06$ & $\mathrm{ND}$ \\
\hline \multirow{3}{*}{ Miasetil (ppm) } & $\mathrm{A}$ & $0.80 \pm 0.58$ & $1.46 \pm 0.49$ & $1.97 \pm 1.19$ \\
\cline { 2 - 5 } & $\dot{\mathrm{I}}$ & $1.62 \pm 1.05$ & $1.62 \pm 0.10$ & $2.58 \pm 0.93$ \\
\cline { 2 - 5 } & $\mathrm{K}$ & $0.90 \pm 0.52$ & $1.32 \pm 0.49$ & $1.45 \pm 0.55$ \\
\hline \multirow{3}{*}{ Butilbutirat (ppm) } & $\mathrm{A}$ & $0.06 \pm 0.11$ & $0.13 \pm 0.23$ & $8.84 \pm 3.55$ \\
\cline { 2 - 5 } & $\dot{\mathrm{I}}$ & $\mathrm{ND}$ & $\mathrm{ND}$ & $12.87 \pm 5.17$ \\
\cline { 2 - 5 } & $\mathrm{K}$ & $0.03 \pm 0.05$ & $\mathrm{ND}$ & $11.44 \pm 5.67$ \\
\cline { 2 - 5 } & $\mathrm{A}$ & $7.65 \pm 2.38$ & $12.17 \pm 6.98$ & $5.41 \pm 9.37$ \\
\cline { 2 - 5 } & $\dot{\mathrm{I}}$ & $14.73 \pm 8.40$ & $16.01 \pm 0.92$ & $12.32 \pm 10.67$ \\
\hline \multirow{3}{*}{ Ethylacetate (ppm) } & $\mathrm{K}$ & $7.27 \pm 4.49$ & $11.56 \pm 2.88$ & $6.87 \pm 3.05$ \\
\cline { 2 - 5 } & $\mathrm{A}$ & $11.86 \pm 11.27$ & $9.15 \pm 8.27$ & $0.61 \pm 0.16$ \\
\cline { 2 - 5 } & $\dot{\mathrm{I}}$ & $2.66 \pm 2.23$ & $7.17 \pm 5.70$ & $0.31 \pm 0.06$ \\
\hline & $\mathrm{K}$ & $1.31 \pm 0.79$ & $30.73 \pm 29.28$ & $0.29 \pm 0.07$ \\
\hline
\end{tabular}

* A: Koumiss which is produced from horse milk, I: Koumiss which is produced from cow milk, K: Koumiss which is produced from goat milk; ND: Not detected.

At the end of storage ( $30^{\text {th }}$ day) it was observed that no acetoin detected in cow and goat milk koumiss, the amount of acetoin (0.10- $0.29 \mathrm{ppm})$ horse milk koumiss at the end of storage. Güzel-Seydim et al. [45] reported in their study that while the amount of acetoin of kefir on the $1^{\text {st }}$ day was $25 \mu \mathrm{g} / \mathrm{g}$, decreased to $16 \mu \mathrm{g} / \mathrm{g}$ on the $21^{\text {st }}$ day of the storage. It shows similarity to koumiss study in terms of decrease in acetoin amount at the end of the storage.

When diacetyl values were examined, a slight increase was generally observed during the storage period. The highest amount of diacetyl was found in the sample of cow milk koumiss. The highest diacetyl $(1.45-2.58 \mathrm{ppm})$ values were reached on the $30^{\text {th }}$ day of storage.

Topuz [25] found that diacetyl amount as $6.52 \mathrm{ppm}$ on first day $6.86 \mathrm{ppm}$ on day 7, 6.37 ppm on day 14 and 5.42 ppm on day 21 in koumiss produced of traditional culture.

The amount of methanol in all koumiss at the end of storage was determined to be between 8.84-12.87 ppm. Magalhães et al. [46] reported that methanol as being highly toxic. According to Ethylalcohol Council Regulation (EECNo. 1576/89) the maximum legal limit is set as $1000 \mathrm{ppm}$ [47]. The values found in all koumiss samples were obderved to be well below the legal limit.

The highest butylbutyrate $(16.00 \mathrm{ppm})$ content was found on the $15^{\text {th }}$ day of storage in the sample of cow milk koumiss. Esters are produced through fermentation by microorganisms including bacteria, molds and yeasts such as lactic acid bacteria. Ester 
synthesis is obtained by the esterification and alcoholysis reactions of short and medium chain fatty acids and alcohol catalyzed by esterase, lipase and alcohol alkyltransferase. Esters commonly found in fermented dairy products and milk; defined as etheric, sweet, fermented and yeast produce a fruit-like aroma of such as apple, banana, pear, pineapple [48]. The lowest butylbutyrate $(5.41 \mathrm{ppm})$ content was found in the sample of horse milk koumiss at the end of storage.

Ziino et al. [49] found the ethyl acetate value as 176 on the $30^{\text {th }}$ day of ripening in cheese. In their study, among esters only ethyl acetate reached a high concentration after 7 days and increased rapidly [49]. When koumiss study was analyzed in terms of ethyl acetate content, the highest value $(30.73 \mathrm{ppm})$ was determined on the $15^{\text {th }}$ day storage of sample of goat milk koumiss. The lowest ethyl acetate content $(0.29 \mathrm{ppm})$ was found at the end of the storage period of sample of goat milk koumiss.

\section{Conclusion}

According to the findings obtained, it was determined that biogenic amines (putrescine, histamine, cadaverine, tyramine, tryptamine and phenylethylamine values) in koumiss produced of horse milk, goat milk and cow milk were below the acute toxicity doses. However, it was observed that the histamine value reached to a higher value at the end of storage in koumiss produced of horse milk. Histamine value was found to be statistically differ according to milk type ( $\mathrm{p}<0.01)$. Among the aroma substances; acetaldehyde, acetoin, diacetyl, methanol, butylbutyrate, ethyl acetate values were found to have no effect on the milk type.

Although horse milk is the most suitable milk for the production of koumiss, it is thought that due to being economical and healthy, the modified cow and goat milk can be used for the production of koumiss when needed.

Acknowledgements. This work was supported by the

TÜBİTAK 2209 BIDEB (Yurt içi) University student projects.

\section{References}

1. Üçüncü M., Balcı M.C. (1992), Kımız ve beslenmedeki önemi, 1. Ulusal Beslenme ve Diabetik Kongresi 14-16th October, Ankara.

2. Tegin R.A.A. (2012), Narın bölgesinde üretilen kımızların bazı kimyasal ve mikrobiyolojik özelliklerinin araştırılması, MS thesis, Kırgızistan Türkiye Manas Üniversitesi Fen Bilimleri Enstitüsü Gıda Mühendisliği Anabilim Dall.

3. Oğuzhan P., Yangılar F., Çelik P. (2013), Eşsiz bir içeceğimiz: kımız, Erzincan University Journal of Science and Technology, 6(1), pp. 223-234

4. Yaygın H. (1991), Kımızın nitelikleri ve sağlıkla ilgili özellikleri, Gıda, 16(2), pp. 111-115.

5. Küçükçetin A. (1999), Kısrak sütü ve farklı oranlarda peynir altı suyu tozu katılmış inek ve keçi sütünden yapılan kımızın özellikleri üzerine araştırmalar, MS thesis, Akdeniz Üniversitesi. Fen Bilimleri Enstitüsü, Antalya.

6. Küçükçetin A. (2003), Kısrak sütü ve membran teknolojileri kullanılarak kısrak sütüne benzetilmiş inek sütünden yapılan kımızın özellikleri üzerine araştırmalar, $P h D$ thesis, Akdeniz Ü. Fen Bil. Ens., Antalya. 
7. Kücükcetin A., Yaygın H., Hinrichs J., Kulozik U. (2003), Adaptation of bovine milk towards mares' milk composition by means of membrane technology for koumiss manufacture, International Dairy Journal, 13(12), pp. 945-951.

8. Yüksekdağ Z.N., Beyatlı Y. (2003), Kefir mikroflorası ile laktik asit bakterilerinin metabolik, antimikrobiyal ve genetik özellikleri, Orlab On-Line Mikrobiyoloji Dergisi, 1(2), pp. 49-69.

9. Nuraeni E., Arief II., Soenarno M.S. (2014), Characteristics of probiotic koumiss from goat milk with addition of roselle extract (Hibiscus Sabdariffa Linn), Journal of the Indonesian Tropical Animal Agriculture, 39(2), pp. 117-125.

10. (1995a), AOAC Official methods of analysis, 16th edn., Washington: Association of Official Analytical Chemists.

11. Marshall R.T. (1992), In Standard methods for the examination of dairy products. 16th edn., Washington, DC, USA: American Public Health Association, 13-46.

12. (1990a), AOAC Official methods of analysis, Association of Official Analytical Chemists Inc., Virginia, USA.

13. (1990b), AOAC Acidity in milk. In, Official methods of analysis. 15th edn., Helrich K. (ed.), Association of Official Analytical Chemists, Washington, USA.

14. (1995b), AOAC Approved methods of the AOAC. 15th edn., Arlington, VA.

15. Özdestan Ö., Üren A. (2006), Biyojen amin analiz yöntemleri, Akademik Glda, 4(20), pp. 19-24.

16. Frank D.C., Owen C.M., Patterson J. (2004), Solid phase microextraction (SPME) combined with gas-chromatography and olfactometry-mass spectrometry for characterization of cheese aroma compounds, LWT-Food Science and Technology, 37(2), pp. 139-154.

17. Anonymous (1987), de man, rogosa and sharpe agar with sorbic acid (MRS-S agar), International Journal of Food Microbiology, 5, pp. 230-232.

18. Davis J.G. (1951), Recommended by the American Public Health Association (APHA), Milk Testing - Dairy Industries Ltd., London, 131.

19. Düzgüneş O., Kesici T., Kavuncu O., Gürbüz F. (1987), Araştırma ve deneme metotları, A.Ü. Ziraat Fakültesi Yayınları: 1021, Ankara, 381.

20. İkiz F., Püskülcü H., Eren Ş. (2012), İstatistiğe giriş, Barış Yayınları Fakülteler Kitabevi. Bornova, İzmir, 445.

21. Malacarne M., Martuzzi F., Summer A., Mariani P. (2002), Protein and fat composition of mare's milk: some nutritional remarks with reference to human and cow's milk, International Dairy Journal, 12(11), pp. 869-877.

22. Potočnik K., Gantner V., Kuterovac K., Cividini A. (2011), Mare's milk: composition and protein fraction in comparison with different milk species, Mljekarstvo: časopis za unaprjeđenje proizvodnje i prerade mlijeka, 61(2), pp. 107-113.

23. Uniacke-Lowe T., Fox P.F. (2011), Equid milk, In: J.W. Fuquay, P.F. Fox, P.L.H. McSweeney (Eds.) (2nd edn.), Encyclopedia of dairy sciences, San Diego, CA, USA: Academic Press), 518-529.

24. Akuzawa R., Surono I.S. (2003), Fermented milks: Asia, In: Encyclopedia of Dairy Sciences, (Roginski H, Fuquay J.W. \& Fox P.F., Eds., Academic Press, London, 1045-1049.

25. Topuz O. (2005), Farklı starter kültürler ve geleneksel kımız mayası ile üretilen kımızların özellikleri üzerine araştırmalar. MSc thesis Akdeniz Üniversitesi. Fen Bilimleri Enstitüsü, Antalya.

26. Kınık Ö., Akalın S., Gönç S. (2000), Kımız üretimi ve özellikleri üzerine bir araştırma, Gıda, 25(5), pp. 379-384.

27. Choi S.H. (2016), Characterization of airag collected in Ulaanbaatar, Mongolia with emphasis on isolated lactic acid bacteria, Journal of Animal Science and Technology, 58(1), pp. 10. 
28. Uniacke-Lowe T. (2011), Koumiss, In: J.W. Fuquay, P.F. Fox, P.L.H McSweeney (Eds.) (2nd ed.) Encyclopedia of dairy sciences, San Diego, CA, USA, Academic Press, 512-517.

29. Kozhahmetova Z., Kasenova G. (2013), Selection of lactic acid bacteria and yeast for koumiss starter and its impact on quality of koumiss, ATI-Applied Technologies \& Innovations, 9, pp. 138-142.

30. Aygün A. (2003), Biyojen aminler - süt ve süt ürünlerindeki varlığı ve önemi, Uludag Univ. J. Fac. Vet. Med., 22(1-2-3), pp. 91-95.

31. Perin L.M., Nero L.A. (2017), The relevance of biogenic amines in dairy products, In Dairy in Human Health and Disease Across the Lifespan, pp. 169-182.

32. Santos M.S. (1996), Biogenic amines: their importance in foods, International Journal of Food Microbiology, 29(2-3), pp. 213-231.

33. Buňková L., Adamcová G., Hudcová K., Velichová H., Pachlová V., Lorencová E., Buňka F. (2013), Monitoring of biogenic amines in cheeses manufactured at small-scale farms and in fermented dairy products in the Czech Republic, Food Chemistry, 141(1), pp. 548-551.

34. Til H.P., Falke H.E., Prinsen M.K., Willems M.I. (1997), Acute and subacute toxicity of tyramine, spermidine, spermine, putrescine and cadaverine in rats, Food and Chemical Toxicology, 35(3-4), pp. 337-348.

35. Shalaby A.R. (1996), Significance of biogenic amines to food safety and human health, Food research international, 29(7), pp. 675-690.

36. 39 Aygün O., Schneider E., Scheuer R., Usleber E., Gareis M., Märtlbauer E. (1999), Comparison of ELISA and HPLC for the determination of histamine in cheese, Journal of Agricultural and Food Chemistry, 47(5), pp. 1961-1964.

37. Karovičová J., Kohajdová Z. (2005), Biogenic amines in food, Chem. Pap., 59(1), pp. 70 79.

38. Ten Brink B., Damink C., Joosten H.M.L.J., In't Veld J.H. (1990), Occurrence and formation of biologically active amines in foods, International Journal of Food Microbiology, 11(1), pp. 73-84.

39. Halasz A., Barath A., Simon-Sarkadi L., Holzapfel W. (1994), Biogenic amines and their production by microorganisms in food, Trends in Food Science \& Technology, 5(2), pp. 42 49.

40. Düz M., Fidan A.F. (2016), Biyojen aminler ve etkileri, Kocatepe Veteriner Dergisi, 9(2), pp. 114-121.

41. Kılıç B. (2008), Türkiye'de üretilen pastırma, sucuk, peynir gibi gıda örneklerindeki biyojenik aminlerin belirlenmesi, MSc thesis Zonguldak Karaelmas Üniversitesi, Fen Bilimleri Ensitüsü, Zonguldak.

42. Panoutsopoulos G.I., Kouretas D., Gounaris E.G., Beedham C. (2004), Metabolism of $2-$ phenylethylamine and phenylacetaldehyde by precision-cut guinea pig fresh liver slices, European Journal of Drug Metabolism and Pharmacokinetics, 29(2), pp. 111-118.

43. Souza S.C., Theodoro K.H., Souza É.R., Motta S.D., Glória M.B.A. (2010), Bioactive amines in Brazilian wines: types, levels and correlation with physico-chemical parameters, Brazilian Archives of Biology and Technology, 48(1), pp. 53-62.

44. Özdestan Ö., Üren A. (2010), Biogenic amine content of kefir: A fermented dairy product, European Food Research and Technology, 231(1), pp. 101-107.

45. Güzel-Seydim Z., Kök-Taş T., Greene A.K. (2010), Kefir and koumiss: microbiology and technology, In: Development and Manufacture of Yogurt and Other Functional Dairy Products, (Yildiz F. (eds) CRC Press Taylor \& Francis Group, London, New york), 143163.

46. Magalhães K.T., Dias D.R., de Melo Pereira G.V., Oliveira J.M., Domingues L., Teixeira J.A., Schwan R.F. (2011). Chemical composition and sensory analysis of cheese whey-based beverages using kefir grains as starter culture, International Journal of Food Science Technology, 46(4), pp. 871-878. 
47. Geroyiannaki M., Komaitis M.E., Stavrakas D.E., Polysiou M., Athanasopoulos P.E., Spanos M. (2007), Evaluation of acetaldehyde and methanol in greek traditional alcoholic beverages from varietal fermented grape pomaces (Vitis vinifera L.), Food Control, 18(8), pp. 988-995.

48. Rincon-Delgadillo M.I., Lopez-Hernandez A., Wijaya I., Rankin S.A. (2012), Diacetyl levels and volatile profiles of commercial starter distillates and selected dairy foods, Journal of Dairy Science, 95(3), pp. 1128-1139.

49. Ziino M., Condurso C., Romeo V., Giuffrida D., Verzera A. (2005), Characterization of "Provola dei Nebrodi", a typical Sicilian cheese, by volatiles analysis using SPME-GC/MS, International Dairy Journal, 15(6-9), pp. 585-593. 